Esta publicación cientifica en formato digital es continuidad de la revista impresa ISSN-Versión Impresa 0798-1406 / ISSN-Versión on line 2542-3185Depósito legal pp
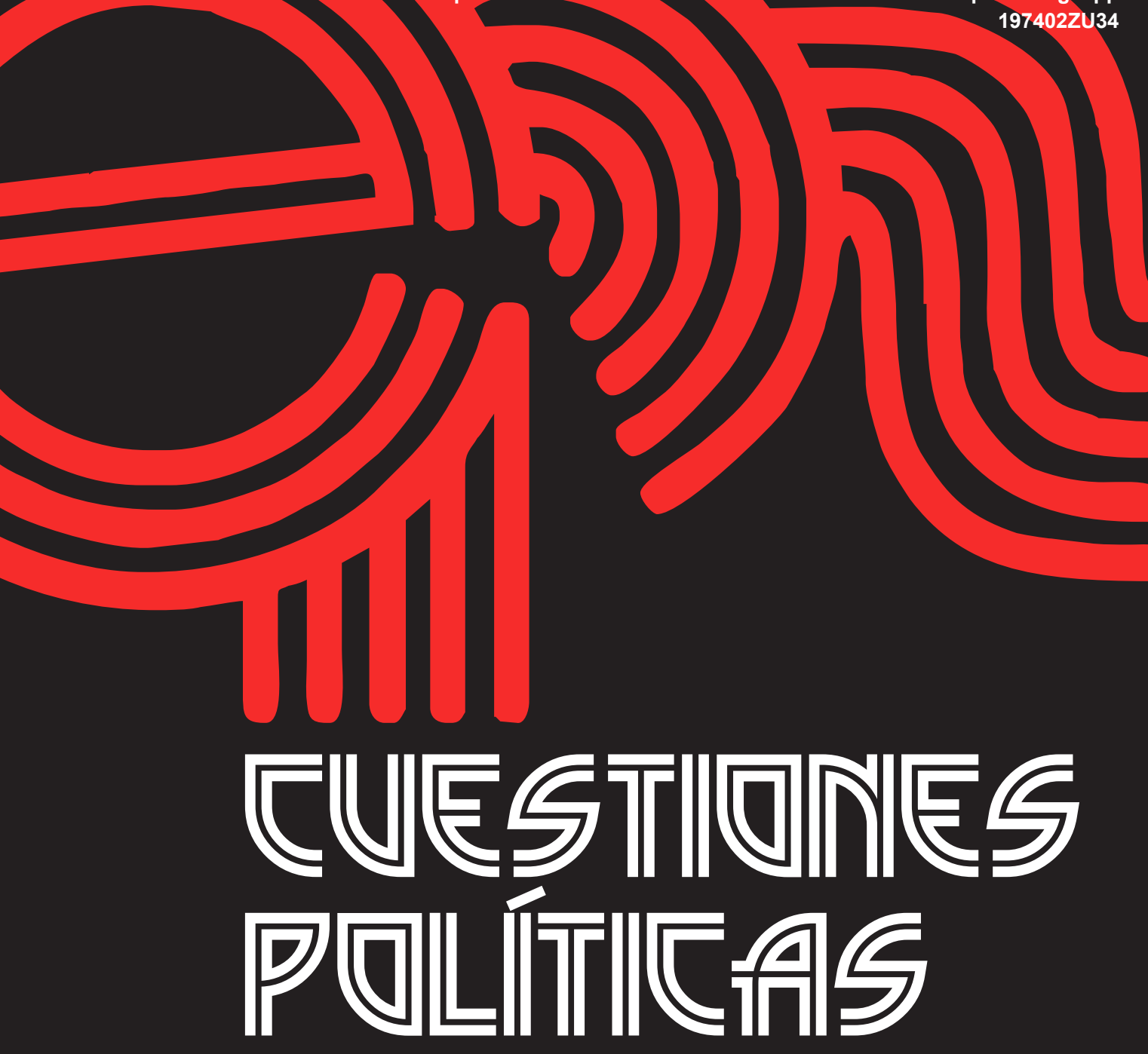

Instituto de Estudios Políticos y Derecho Público "Dr. Humberto J. La Roche" de la Facultad de Ciencias Jurídicas y Políticas de la Universidad del Zulia Maracaibo, Venezuela
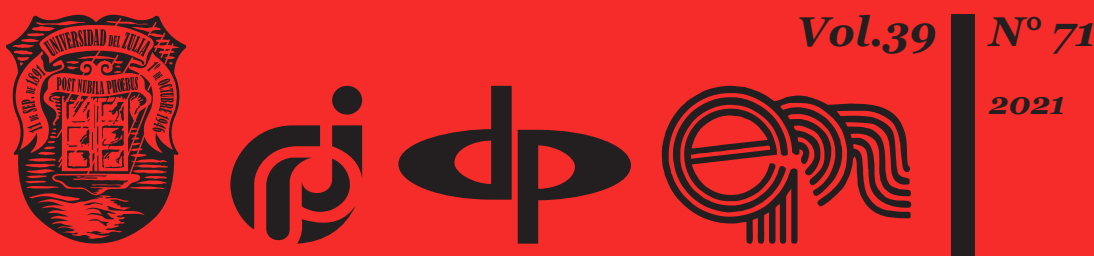


\title{
Legal regulation of combating illegal migration in Ukraine and the EU
}

\author{
DOI: https://doi.org/10.46398/cuestpol.3971.26
}

\author{
Yurii Kuryliuk * \\ Mariia Slyvka ** \\ Yaroslav Kushnir ***
}

\begin{abstract}
Through a methodology of legal interpretation and analyze the stages of formation of migration policy and legislation in Ukraine since its independence. It was determined that in the initial stage the main elements of the legal regulation of migration processes in Ukraine were the development of the legal framework on migration, the initiation of international cooperation and the creation of organizational structures that address migration issues. The article also analyzes the extensive system of normative acts developed in Ukraine today, aimed at the legal regulation of migration processes and the fight against illegal migration. In this context, the details of the fight against illegal immigration in EU countries are described. Finally, the guidelines for EU migration policy in the field of combating illegal immigration are studied. It is concluded that, unlike Ukraine, where the fight against illegal immigration is mainly limited to the establishment of prohibitions and fines for illegal immigrants, the EU has developed a system of incentives and measures aimed at supporting third
\end{abstract} countries, among other aspects.

Keywords: illegal migration; migration processes; immigration legislation; immigration in Europe; refugees and asylum.

Head of Department of Administrative Jurisdiction of Administration of the State Border Guard Service of Ukraine, Kyiv, Ukraine. ORCID ID: https://orcid.org/0000-0002-4035-4431

** Assistant of Department of Administrative and Information Law of the Educational-Scientific Institute of Law, Psychology and Innovative Education of Lviv Polytechnic National University, Lviv, Ukraine. ORCID ID: https://orcid.org/0000-0003-2679-1632

*** Senior Instructor of Administrative Activity Department of National Academy of State Border Guard Service of Ukraine named after Bogdan Khmelnitskiy, Kyiv, Ukraine. ORCID ID: https://orcid.org/0000-0002-8519-5331 


\section{Regulación legal de la lucha contra la inmigración ilegal en Ucrania y la Union Europea}

\section{Resumen}

Mediante una metodología de interpretación jurídica se analizan las etapas de formación de la política y la legislación migratoria en Ucrania desde su independencia. Se determinó que en la etapa inicial los principales elementos de la regulación legal de los procesos migratorios en Ucrania fueron el desarrollo del marco legal sobre migración, el inicio de la cooperación internacional y la creación de estructuras organizativas que atiendan los temas migratorios. El artículo además analiza el extenso sistema de actos normativos desarrollado en Ucrania hoy, destinado a la regulación legal de los procesos migratorios y la lucha contra la migración ilegal. En este contexto, se describen los detalles de la lucha contra la inmigración ilegal en los países de la UE. Por último, se estudian las orientaciones de la política de migración de la UE en el ámbito de la lucha contra la inmigración ilegal. Se concluye que, a diferencia de Ucrania, donde la lucha contra la inmigración ilegal se limita principalmente al establecimiento de prohibiciones y multas para los inmigrantes ilegales, la UE ha desarrollado un sistema de incentivos y medidas destinadas a apoyar a terceros países, entre otros aspectos.

Palabras clave: migración ilegal; procesos migratorios; legislación migratoria; inmigración en Europa; refugiados y asilo.

\section{Introduction}

At the present stage of Ukraine's development, changes and processes are taking place, which primarily cover the political sphere, and therefore require a deeper scientific understanding. Migration policy is no exception, which, depending on internal and external circumstances, must be formed in accordance with the requirements of the time, considering primarily the interests of society and the state. In terms of economic and political crisis, the imperfection of legal regulation of migration processes is rather important.

A serious issue that Ukraine has faced in recent years is the growth of illegal migration. Socio-economic instability in the world has made Ukraine attractive not only to refugees forced to flee persecution, but also to immigrants from many Asian and African countries suffering from poverty, hunger, unemployment, and power struggles. In various, often illegal ways, they are trying to reach Ukraine in order to cross the West. However, in recent years there has been an obvious tendency to transform 


\section{4 \\ Yurii Kuryliuk, Mariia Slyvka y Yaroslav Kushnir \\ Legal regulation of combating illegal migration in Ukraine and the EU}

Ukraine from a transit country to a destination country for migrants. Due to the aggravation of entry procedures in Central and Western Europe, a significant number of illegal migrants remain in Ukraine.

After the accession of Ukraine's western neighbors to the European Union, the attractiveness of the route through the territory of Ukraine for illegal migrants has increased sharply, at the same time the question of the need to regulate this phenomenon has become acute for society. That is why migration problems in Ukraine become especially politically acute and relevant and need political, regulatory, organizational systematization.

Illegal migration has a pronounced transit character - illegal migrants try to enter Ukraine from Russia, Belarus, by air or sea, and then illegally leave for Slovakia, Hungary, or Poland and then to other Western European countries. Illegal migrants enter Ukraine using legal means of entry (under the guise of tourism, visiting relatives, in private) or illegal (crossing the border outside checkpoints or through checkpoints with forged documents), mostly from Russia.

The important point is that for some migrants Ukraine becomes not only a transit territory, but also a place of long-term stay, sometimes consciously chosen country of residence. As a result, illegal migrants are accumulating in the country. Due to the unsettled status of their stay in Ukraine, these people often find themselves in rather difficult circumstances. At the same time, the uncertainty of their situation is a factor in creating additional tensions in the socio-economic and interethnic spheres, the deterioration of the criminogenic situation. A significant number of illegal migrants are concentrated in the city of Kyiv and border regions. This is where they try to get to Western Europe. The growth of illegal migration to Ukraine poses a real threat to the public security of our country. Persons from among foreigners commit various crimes on the territory of our country, including serious criminal ones.

It is worth noting that the European Union itself suffers from the problems of illegal migration. After 2014, the refugee crisis in the EU intensified, because of which the EU was forced to adopt a number of regulations and legal measures aimed at stopping the growth of illegal migrants.

These issues highlight the need to study the problems of legal regulation of migration processes, as well as the specifics of combating illegal migration in Ukraine and the European Union. 


\section{Formation of bases of legal regulation of migration policy in Ukraine.}

The beginning of the legal regulation of migration processes in independent Ukraine can be considered the Declaration of State Sovereignty, which was adopted in 1990. Here it was first stated that Ukraine "regulates immigration processes" (USSR, 1990). At the same time, the Law of Ukraine "On Rehabilitation of Victims of Political Repression in Ukraine", which guaranteed the repressed, deported and their descendants (along with the restoration of other violated rights) the opportunity to return to their places of residence, was adopted in 1991(Verkhovna Rada of Ukraine, 1991). The Law of Ukraine "On Citizenship of Ukraine" defined the right to citizenship of immigrants from Ukraine who returned to its territory (Verkhovna Rada of Ukraine, 2001).

As the share of forced displacements in the mass influx of population to Ukraine in the early 1990 os was significant, the state paid special attention to this problem. The concept of refugee status was first introduced in the summer of 1992, when Ukraine accepted more than 60,000 refugees from the Transnistrian military conflict zone. To resolve their legal status, the Cabinet of Ministers of Ukraine approved the Provisional Regulation on the Procedure for Determining the Status of Refugees from the Republic of Moldova and Providing Assistance to Them (Verkhovna Rada of Ukraine, 1992).

This was the first legislative document directly aimed at resolving the migration problem. The experience of its implementation and the scale of forced migration proved the need to develop a special law in this area, so the Verkhovna Rada of Ukraine adopted the Law of Ukraine "On Refugees and Persons in Need of Additional or Temporary Protection" (Verkhovna Rada of Ukraine, 2011). To implement it, local bodies of the migration service were created, which were to consider applications for refugee status in Ukraine, make decisions on them, organize assistance to refugees (Dergach, 2013).

Considerable attention in the field of legal regulation of migration processes in Ukraine was paid to ensuring the right of their own citizens to freedom of movement leaving the country and returning home. This provided for the abandonment of Soviet permitting procedures for emigration, total control over travel abroad. As early as January 1993, in accordance with the Resolution of the Cabinet of Ministers, the procedure according to which a citizen had to obtain a permit from the competent authorities for each border crossing was abolished. The Parliament adopted the Law of Ukraine "On the Procedure for Leaving Ukraine and Entering Ukraine by Citizens of Ukraine", which guaranteed the right to freely exercise the relevant rights (Verkhovna Rada of Ukraine, 1994). With its adoption, the provisions of 
the Law of Ukraine "On Employment" came into force, which allowed labor or entrepreneurial activity of citizens during a temporary stay abroad, i.e., labor migration (Verkhovna Rada of Ukraine, 2012).

This law also contained provisions according to which bureaus, agencies, and other organizations, i.e., labor migration infrastructure, could be established for the employment of citizens of Ukraine during their temporary stay abroad. To carry out business activities, these structures had to obtain licenses from the state employment service (Malinovskaya, 2010).

Nevertheless, after the collapse of the Soviet Union, due to the lack of legally bound borders, Ukraine found itself at the center of migration flows, which led to the uncontrolled movement of foreigners. This situation required legal regulation of immigration into the country and determination of the legal status of foreigners. As a result, the Law of Ukraine "On the Legal Status of Foreigners and Stateless Persons" was adopted, according to which foreigners permanently residing in Ukraine received rights (other than the right to elect and be elected to hold public office) and had to perform their duties (except for military service).

The law established the rules of stay of foreign citizens, their departure and entry, provided for liability for violation of the relevant rules (reduction of the period of stay, the order of expulsion). It enshrined the possibility of immigration to Ukraine, asylum, refugee status, citizenship. These issues were to be regulated by special laws the immigration law, which was planned to be adopted (Kushnir et al., 2021).

In order to prevent illegal migration, the first State Program to Combat Illegal Migration was approved in 1996. This program provided for organizational and practical measures, which included the creation of special units within the structure of the Ministry of Internal Affairs; prevention of offenses related to illegal migration; international cooperation in the fight against illegal migration by signing bilateral agreements on mutual legal assistance; improving the legal framework for immigration. The practice of developing such programs continued in the future (Cabinet of Ministers of Ukraine, 1996).

The adoption of the Constitution of Ukraine on June 26, 1996, was of great importance for the further development of legal regulation of migration processes (Verkhovna Rada of Ukraine, 1996). It is expedient to identify three areas of development of migration legislation: bringing current regulations in line with the Constitution of Ukraine; adoption of new laws that do not contradict the Constitution and harmonization of Ukrainian legislation with international law.

Considering these areas, it should first be noted that the Constitution of Ukraine is the basic law on which the legal system of the country should 
be based. The Constitution contains provisions that stipulate the need to adopt specific laws on the implementation of migration policy: Laws of Ukraine: "On Citizenship of Ukraine" (Verkhovna Rada of Ukraine, 2001), "On Immigration" (Verkhovna Rada of Ukraine, 2001), "On the legal status of foreigners and stateless persons" (Verkhovna Rada of Ukraine, 2011).

The Constitution enshrines the basics of legal regulation of migration processes in Ukraine regarding the movement of people, namely: everyone who is legally on the territory of Ukraine is guaranteed freedom of movement, free choice of residence, the right to leave Ukraine, except for restrictions established by law (Art. 33).

The Constitution provides for the possibility of establishing restrictions on freedom of movement on the territory of Ukraine and the choice of place of residence in a state of war and emergency (Article 64). This applies equally to citizens of Ukraine, foreigners, stateless persons. Restrictions should be temporary, pending the imposition of such a state of war, natural disasters, accidents or catastrophes, epidemics, epizootics, and other force majeure.

Thus, the Constitution of Ukraine reflects various aspects of migration processes, establishes the basics of regulation of these processes, the right to freedom of movement and free choice of residence. It the basis for further legislative and rule-making activities in the field of migration, its rules have a special priority in the regulatory system of Ukraine.

Thus, by the beginning of the twentieth century the main elements of the legal regulation of migration processes in Ukraine were formed: the legal framework on migration issues was developed, international cooperation was initiated, and organizational structures dealing with migration issues were established.

\section{Basic principles of legal regulation of migration processes and counteraction to illegal migration in Ukraine}

During the harmonization of the legal framework with the international one, many shortcomings were revealed. From the assessment of the effectiveness of legal norms followed the task of improving them. The adoption of the Constitution and Ukraine's accession to the most important international legal agreements in the field of human rights, in particular, to the European Convention on Human Rights and Fundamental Freedoms, required the migration legislation to be brought into line with these documents. Thus, in order to protect the interests of migrant workers, the Law of Ukraine "On Licensing of Certain Types of Economic Activity" was adopted. 
Yurii Kuryliuk, Mariia Slyvka y Yaroslav Kushnir
478 Legal regulation of combating illegal migration in Ukraine and the EU

During 2001, several basic legislative acts on migration regulation were adopted, in particular, new versions of the laws "On Citizenship of Ukraine", "On Refugees" (repealed), as well as laws "On Immigration", "On Amendments to Certain Legislative Acts of Ukraine on Combating Illegal Migration" (Verkhovna Rada of Ukraine, 2001).

In December 2003, the Parliament adopted the Law of Ukraine "On Freedom of Movement and Free Choice of Residence in Ukraine" (Verkhovna Rada of Ukraine, 2003), which applied to both citizens of Ukraine and foreigners who were legally in the country.

In 2004, the Law of Ukraine "On Ukrainians Abroad" was approved, which, among other things, fixed the right of this category of foreign citizens to immigrate to Ukraine outside the established quotas (Verkhovna Rada of Ukraine, 2004).

Increased attention to labor migration of Ukrainians abroad was associated with a special report of the Verkhovna Rada of Ukraine Commissioner for Human Rights (April 2003), the subject of which was a violation of human rights in connection with labor migration. Responding to the ombudsman's report, the Parliament held special hearings on the legal and social status of modern Ukrainian labor migration, Ukraine acceded to the European Convention for the Protection of the Rights of Migrant Workers (Libanova, 2010).

The Government has developed a Program for Ensuring the Rights and Interests of Citizens Going Abroad for Employment and Children Adopted by Foreigners. Special units began to operate to combat this phenomenon.

Some norms of the laws "On the Legal Status of Foreigners and Stateless Persons", "On the Procedure for Leaving Ukraine and Entering Ukraine by Citizens of Ukraine", "On Citizenship of Ukraine" were systematically improved by amending them. The development of legal regulators was aimed at more complete protection of human rights, improvement of mechanisms for regulating migration flows (Bil, 2017).

Thus, nowadays the legislation of Ukraine on migration is represented by the system of current laws of Ukraine: "On the procedure for leaving Ukraine and entering Ukraine for citizens of Ukraine", "On the legal status of foreigners and stateless persons", "On Immigration", "On Refugees and Persons in Need of Additional or Temporary Protection", "On Citizenship of Ukraine", "On Freedom of Movement and Free Choice of Residence in Ukraine".

The Law of Ukraine "On Citizenship of Ukraine" is based on the requirements of international legal acts. The Law takes into account the living conditions and interests not only of immigrants, but also of persons who do not have the status of immigrants in Ukraine. 
The connection between the implementation of the provisions of the Law of Ukraine "On Citizenship of Ukraine" and migration can be traced through such an important aspect as the acquisition of Ukrainian citizenship abroad by territorial origin, i.e., immigrants from Ukraine, including persons previously deported outside Ukraine and their descendants who permanently reside in other states. With the acquisition of Ukrainian citizenship, the Law of Ukraine "On the Procedure for Leaving Ukraine and Entering Ukraine by Citizens of Ukraine" applies to them. A citizen of Ukraine is free to enter Ukraine with a national passport.

The connection of the institute of citizenship of Ukraine with migration processes is reflected in the principle of preservation of the citizenship of Ukraine established by the Law regardless of the place of residence of the citizen of Ukraine.

The Law of Ukraine "On Freedom of Movement and Free Choice of Residence in Ukraine" applies to all categories of individuals who are legally on the territory of Ukraine. The law clearly states the grounds determined by law for stay on the territory of Ukraine, the conditions of registration of residence, place of stay, deregistration of residence. The law establishes the grounds (for the territory and for certain categories of persons) that restrict freedom of movement. The adoption of this law is timely and important in resolving migration issues in Ukraine.

The next law in the field of migration is the Law of Ukraine "On the Legal Status of Foreigners and Stateless Persons". It determines the legal status of foreign citizens and stateless persons in Ukraine, establishes the basic rights, freedoms and responsibilities of foreign citizens and stateless persons residing or temporarily staying in Ukraine, as well as the procedure for resolving issues related to them.

As the analysis of the legislation shows, the rights of foreigners and stateless persons who are legally on the territory of Ukraine comply with international law, their legal status is determined by the Constitution of Ukraine, the Law of Ukraine "On Legal Status of Foreigners and Stateless Persons" and other laws of Ukraine as well as international agreements. In the case of establishing by an international agreement other rule than those provided by law, the rules provided by such an international agreement of Ukraine shall apply (Dergach, 2015).

Immigration to Ukraine is carried out both out of quota and in accordance with quotas. The Cabinet of Ministers of Ukraine for each calendar year sets the maximum number of persons in the categories defined by the Law "On Immigration" who can immigrate to Ukraine. The law also provides for the issuance of immigration permits outside quotas for certain categories of foreigners, especially those from Ukraine, regulates the departure and expulsion of persons from Ukraine in connection with the revocation of 
immigration permits, appeals against immigration decisions, actions, or inaction of public authorities.

The Law of Ukraine "On Refugees and Persons in Need of Additional or Temporary Protection" regulated the issue of one of the categories of foreigners and stateless persons. It established the procedure for granting and revoking refugee status, appealing against decisions on refugees, the rights and obligations of refugees and persons in need of additional protection, the powers of executive bodies to decide on persons seeking recognition as a refugee or a person in need of additional protection. The law defines the terms "refugee" and "person in need of subsidiary protection", which clearly corresponds to the definition provided by the UN Convention relating to the Status of Refugees, adopted on 28 July 1951 (United Nations' 1951).

Migration issues are also regulated by a number of resolutions of the Verkhovna Rada of Ukraine. Among them the resolution of June 17, 1999 "On the Principles of the State Policy of Ukraine in the Field of Human Rights" is important. In this document, the main directions of state policy in the field of human rights migration include:

- strengthening the reality of the right to freedom of movement and free choice of place of residence in Ukraine (by abolishing the institution of residence).

- humanization and effective implementation of legislation on refugees and internally displaced persons.

- promoting the development of a system of non-judicial protection of human rights and freedoms, providing support to public organizations in the field of human rights protection (Verkhovna Rada of Ukraine, 1999).

Obvious progress in the field of legal regulation of migration processes was ensured due to a number of important decisions taken in Ukraine during 2011-2015, in particular, approval of the Concept of State Migration Policy (President of Ukraine, 2011), establishment of the State Migration Service (President of Ukraine, 2014) and its territorial subdivisions (Cabinet of Ministers of Ukraine, 2011).

In order to improve the legislation aimed at combating illegal migration across the state border of Ukraine, it was decided to amend the Criminal Code of Ukraine (Verkhovna Rada of Ukraine, 2001), Criminal Procedure Code of Ukraine (Verkhovna Rada of Ukraine, 2012) and the Code of Administrative Offenses of Ukraine (Verkhovna Rada of Ukraine, 1984) in terms of strengthening liability for illegal crossing of the state border of Ukraine, violations by foreigners and individuals without citizenship rules of stay in Ukraine and transit through the territory of Ukraine, violation of 
employment, housing, registration, or discharge of foreigners and stateless persons and registration of documents for them, deportation outside Ukraine. The functions of combating illegal migration were entrusted to the intelligence agencies of Ukraine, which, in addition, participated in the fight against international organized crime, including terrorism, drug trafficking, illicit arms trafficking and its technology, as well as specially authorized body of executive power for the protection of the state border of Ukraine - to ensure the interests of the state in the areas of border and immigration policy, as well as in other areas related to the protection of the state border of Ukraine and its sovereign rights in the exclusive (maritime) economic zone and continental shelf (Dergach, 2016).

Illegal migration is identified among the main real and potential threats to Ukraine's national security and stability in society. In this regard, it is decided that the main directions of state policy in the fight against illegal migration will be addressed through the participation of the state in international cooperation (Mikolaichuk, 2010). The decision on freedom of movement and free choice of residence was made in accordance with the Constitution of Ukraine and aimed to regulate relations related to freedom of movement and free choice of residence in Ukraine, guaranteed by the Constitution of Ukraine (Freika et al., 1999).

Thus, in Ukraine the main areas of legal regulation to combat illegal migration are: implementation of international migration law in domestic law; definition of the basic rules of behavior of the migrant in laws; identification of correlation between state border legislation and migration legislation; emergence of separate legislation regulating entry into and exit from the temporarily occupied territory of Ukraine; openness of the legal system of Ukraine to the application of new sources of law, in particular decisions of international and national courts.

\section{Legal regulation of combating illegal migration in the EU countries}

After the consolidation of legislative powers in the field of regulation of migration processes for the EU institutions, a number of normative legal acts were adopted aimed at introducing uniform rules in relation to illegal immigrants in the EU countries. On May 28, 2001, the Council adopted Directive 2001/40/EC on the mutual recognition of decisions on the expulsion of third-country nationals (Council of the European Union, 2001). The document states that a decision to expel an illegally staying alien made by one of the member states is subject to execution by other member states, on whose territory the person may later be. 
In order to simplify the procedure for the expulsion of illegal immigrants from the EU Member States, Directive 2003/110 / EC of November 25, 2003, "On assistance in cases of transit for the purposes of removal by air" (Council of the European Union, ${ }^{2003)}$ was adopted. The beginning of the unification of criminal legislation in the field of combating illegal immigration in the EU is the adoption of EU Council Directive No. 2002/90 / EC of November 28, 2002 "On the definition of facilitation of unauthorised entry, transit and residence" (Council of the European Union, 2002). Directive 2002/90 / EC contains definitional norms and establishes general signs of criminal acts, consisting in facilitating the illegal entry of foreigners into the territory of the Member States.

Since 2014, the European Union has been actively fighting the refugee crisis, which turned out to be the biggest humanitarian problem for the EU in its entire history (Butorina and Kaveshnikova, 2016). In 2015, the number of illegal migrants to the European Union from third countries has exceeded 1 million, it was a record year for the intensity of migration flows to the EU. Frontex recorded 1.8 million cases of illegal migration in 2015, including 1.04 million of them in Greece and Italy. However, both countries are only "trans-shipment points", since most illegal migrants strive further, to more developed EU countries, in particular to Germany, Great Britain, France and the Scandinavian countries (Bolshova, 2016).

On May 13, 2015, the European Commission published a message "The European Agenda for Migration", in which it outlined a plan for short-term and long-term EU actions to overcome the migration crisis (European Commission, 2015). An important part of the agenda was the development of an action plan to combat the smuggling of migrants (Chacon Hernandez, 2021). Two weeks later (on May 27, 2015), the European Commission prepared a communication "EU Action Plan on Combating Migrant Smuggling (2015-2020)", which identified four priority areas of EU policy in this area:

- strengthening of joint actions within the framework of police and judicial cooperation between the EUs countries.

- improvement of the mechanism for data collection and information exchange; stepping up joint action to prevent the smuggling of migrants and provide assistance to the most vulnerable categories of migrants.

- strengthening cooperation with third countries in the field of combating illegal migration (European Commission, 2015).

The document also emphasized that the implementation of the Plan should be considered in the broader context of EU policy in such areas as combating the causes of irregular migration, creating safe legal channels for migration to the EU, general EU policy in the field of security and defense (CSDP), as well as the EU return policy. 
Refugee Crisis 2014-2015 contributed to the strengthening of the external dimension of the EU migration policy. In the period 2014-2016, the EU has intensified its interaction with third countries - sources and transit countries of migrants at different levels: within the framework of the Migration Dialogues at the highest level, the EU summits with Turkey, African and Western Balkan states (Sadykova, 2016), the dialogue on mobility and migration between the EU and Africa, the Budapest and Prague processes, the European neighborhood policy (Potemkina, 2015). The outcome of the EU meetings with third countries on migration issues during this period was the project "New Framework Partnership with Third Countries in the Field of Migration", approved by the EU Council in June 2016. In accordance with this document, partnerships pursue short-term and long-term goals.

The short-term goals are: saving lives in the Mediterranean, increasing the share of illegal migrants returning home, helping migrants and refugees in their places of residence in order to reduce new attempts of illegal migration. In the long term, partnerships are aimed at eliminating negative political, economic, social, climatic, and other factors that are the main causes (root causes) of illegal migration and forced resettlement. The project defines a methodology for the implementation of framework partnerships on migration, which includes five key elements (areas of activity):

1. Increasing the effectiveness of the policy of return, readmission, and reintegration of migrants. These policies are aimed at destroying the business of smugglers and human traffickers working on the principle of "small risks, big profits." A significant increase in the percentage of illegal migrants returning home should significantly weaken the motivation of people to pay money to smugglers to organize their illegal transportation to Europe. To achieve the long-term effect of the return process (prevention of repeated illegal migration), the EU (in cooperation with the International Organization for Migration) promises its partner states active support in the voluntary return and reintegration of returned migrants (Molinari, 2019).

2. Greater coherence and better coordination between the EU and Member States is seen as essential to the success of partnerships with third countries. Some European states (former colonial powers) have closer bilateral relations with specific third countries due to longstanding historical and cultural ties. The EU calls on states with such potential to join forces for the good of a common cause and to make more active use of their influence on third countries in order to facilitate more effective implementation of mutual agreements and obligations within partnerships (in particular, under readmission agreements). At the same time, the document emphasizes the importance of joint work of EU institutions and member states in tandem with each other. 
3. Reorientation of EU policies (methods of their use) to address the problem of illegal migration. Following the meetings in the framework of the High-level Migration Dialogues, the EU prepared proposals for the first packages for concluding contracts (compacts) with 16 third countries (Ethiopia, Eritrea, Mali, Niger, Nigeria, Senegal, Somalia, Sudan, Ghana, Cote d'Ivoire, Algeria, Morocco, Tunisia, Afghanistan, Bangladesh, and Pakistan). Discussions with Member States in June 2016 identified five priority African countries (Ethiopia, Niger, Nigeria, Senegal, and Mali). An individual interaction plan was developed for each country. Individual agreements (compacts) represent a new format of partnerships with third countries, in which the EU has combined its external and sectoral policies (European Neighborhood Policy, Development Assistance Policy, Foreign Trade Policy, Energy Policy, Security Policy, Digital Policy, etc.) into a single system focused on a common goal - to reduce illegal migration. Migration policy is an important component of the Compact (Devisscher, 2011).

The EU plans to strengthen the instruments of this policy in cooperation with third countries:

- introduce a new "structured resettlement system" based on the general approach of providing safe and legal entry into the EU for persons in need of international protection.

- expand channels and opportunities for legal migration to the EU using visa policy instruments.

- develop training programs for migrants, focused on the needs of labor markets in the EU; facilitate remittances of migrants to their home countries.

- to create a single platform for registration of displaced persons in order to accelerate the delivery of necessary assistance to third countries and the implementation of resettlement of refugees to the EU or other countries, etc.

4. Effective multilateralism. The need to develop this area is due to the fact that migration is a global challenge and therefore requires a coordinated international approach. In the past few years, the EU has strengthened cooperation in the field of asylum policy and combating illegal migration with international organizations (UN High Commissioner for Refugees, UN International Organization for Migration), partner countries within the G-7, G-20 groups. In particular, the EU actively cooperates with UN structures in the framework of such programs as the global plan for sharing the burden of responsibility for the resettlement of Syrian refugees, the program of assistance in the voluntary return and reintegration of returned migrants (Provine, 2009). 
5. Consolidation and targeting of EU financial instruments. The EU stresses the important role of the partnership financing mechanism. The choice of these or those financial instruments should be determined by the specific goals of the partnerships. For shortterm purposes of partnerships (assistance to refugees and their host communities), financial instruments are provided such as the Fund for Refugees in Turkey, the EU Regional Investment Fund in connection with the crisis in Syria (Madad Fund), the Trust Emergency Fund for African Countries. For long-term goals (combating the root causes of illegal migration), the EU is betting on stimulating private sector investment in Africa as part of the European External Investment Plan.

In September 2016, the European Commission published an ambitious European External Investment Plan for emerging economies, in particular for Africa and the European Neighborhood. The priority goal of the plan is to promote the social and economic development of third countries by attracting investments. The European Commission has contributed 3.35 billion euros to the External Investment Fund by 2020 and plans to attract another 62 billion euros from other sources - public and private funds, as well as from the budgets of the member states. This fund will provide guarantees to government organizations and the private sector when investing in countries where there are political risks. Any interested company will be able to receive a guarantee for investing in a project that meets certain criteria. In particular, the project should contribute to sustainable development, job creation in third countries and the elimination of the root causes of illegal migration (Blasi Casagran, 2021).

Thus, counteraction to illegal migration in the EU is unfolding in two directions. On the one hand, the EU has developed a system of regulations aimed at introducing uniform rules for illegal immigrants in the EU countries and criminalizing illegal border crossing. On the other hand, the EU implements a system of incentive measures aimed at supporting third countries and facilitating the legalization of migrant flows.

\section{Conclusions}

The analysis of the migration legislation makes it possible to distinguish three types of documents according to their content, related to combating illegal migration in Ukraine: regulatory legal acts determine the model of legal entry of a migrant and stay in the country; law enforcement norms establish responsibility and regulate the application of other coercive measures in case of violation of migration norms; organizational documents determine the competence of the authorities involved in the process of combating illegal migration. 
According to the content of international legal regulations, migration offenses are naturally recognized as illegal. Indication of any other characteristic of migration in violation of the established rules, apart from illegality, pursues a purpose other than that required to establish a certain prohibition.

In Ukraine, the main areas of legal regulation to combat illegal migration have been: implementation of international migration law in domestic law; definition of the basic rules of behavior of the migrant in laws; identification of coercive measures that can be applied to individuals and legal entities involved in migration processes; the correlation between state border legislation and migration legislation; emergence of separate legislation regulating entry into and exit from the temporarily occupied territory of Ukraine; openness of the legal system of Ukraine to the application of new sources of law, in particular decisions of international and national courts.

The protection of the external border and the fight against illegal entry into the territory of the EU is entrusted to national border formations, mainly of the police type, the interaction and coordination of which is provided by a special European agency. EU standards for combating illegal migration in the protection of state codons should be defined as enshrined in EU law principles, assets (values), norms, criteria, forms, and methods of law enforcement, used on the basis of combining humanity and efficiency to regulate the activities of border control authorities.

In contrast to Ukraine, where combating illegal migration is mainly limited to the establishment of bans and fines for illegal migrants, the EU has developed a system of incentives and support measures aimed at supporting third countries. The main areas of combating illegal migration in the EU are: increasing the effectiveness of the policy of return, readmission and reintegration of migrants; greater coherence and better coordination between the EU and Member States, which is seen as essential to the success of partnerships with third countries; reorientation of EU policies (methods of their use) to address the problem of illegal migration; effective multilateralism; consolidation and targeting of EU financial instruments.

\section{Bibliographic References}

BIL, Mykola. 2017. "The effectiveness of the mechanism for regulating population migration: theoretical and methodological foundations of the assessment" In: Regional economy. Vol. 2, No.84, pp. 73-79.

BLASI CASAGRAN, Cristina. 2021. "Fundamental Rights Implications of Interconnecting Migration and Policing Databases in the EU" In: Human Rights Law Review. Vol. 21, No. 2, pp. 433-457. 
BOLSHOVA, Natalia. 2016. "The EU Response to the Refugee crisis of 2015 and the Prospects for a Common EU Migration Policy” In: IIS International Analytics. MGIMO-University. Vol. 1, No. 15, pp. 19-33.

BUTORINA, Olga; KAVESHNIKOVA, Natalia. 2016. European Integration: Textbook for High Schools. Aspekt-Press. Moscow, Russia.

CABINET OF MINISTERS OF UKRAINE. 2011. On the formation of territorial bodies of the State Migration Service. Resolution of the Cabinet of Ministers of Ukraine № 658 from 2011. Available online. In: http:// zakon5.rada.gov.ua/laws/show/658-2011-p. Date of consultation: 05/12/2020.

CHACON HERNANDEZ, David. 2021. "Crisis Migration and Migration Crisis. A Vision from Human Rights In: Ciencia Juridica. Vol. 10, No. 19, pp. 137-160.

COUNCIL OF THE EUROPEAN UNION. 2001. On the mutual recognition of decisions on the expulsion of third country nationals. Council Directive 2001/40/EC from 2001. Available online. In: https://eur-lex.europa. eu/legal-content/EN/TXT/?uri=CELEX\%3A32001L0040. Date of consultation: 05/12/2020.

COUNCIL OF THE EUROPEAN UNION. 2002. Council Directive 2002/90/EC defining the facilitation of unauthorised entry, transit and residence from 2002. Available online. In: https://eur-lex.europa.eu/legal-content/EN/ ALL/?uri=CELEX:32002L0090. Date of consultation: 05/12/2020.

COUNCIL OF THE EUROPEAN UNION. 2003. On assistance in cases of transit for the purposes of removal by air. Council Directive 2003/110/EC from 2003. Available online. In: https://eur-lex.europa.eu/legal-content/en/ ALL/?uri=CELEX\%3A32003L0110. Date of consultation: 05/12/2020.

DERGACH, Anna. 2013. "Legal aspects of migration policy in Ukraine. In: State management and local self-government: collection of scientific works of DRIDU NAPA under the President of Ukraine. Vol. 2, No. 17, pp. 149157.

DERGACH, Anna. 2015. "Theoretical grounds for making effective decisions in the management of migration processes" In: Investments: practice and experience: scientific and practical journal. Vol. 21, pp. 126-129.

DERGACH, Anna. 2016. "Regulatory, organizational and institutional support of financial and economic mechanisms of public administration of migration” In: Evropský časopis ekonomiky a management. Vol. 5, pp. 46-53. 
DEVISSCHER, Purdey. 2011. "Legal Migration in the Relationship between the European Union and ACP Countries: The Absence of a True Global Approach Continues" In: European Journal of Migration and Law. Vol. 13, No. 1, pp. 53-94.

EUROPEAN COMISSION. 2015. EU Action Plan against migrant smuggling (2015-2020). In: COM (2015). Final. Brussels, Belgica.

EUROPEAN COMISSION. 2015. European Agenda on Migration. In: COM (2015) 240 Final. Brussels, Belgium.

FREIKA, Tomas; OKOLSKI, Marek; SWORD, Keith Sword. 1999. In-depth studies on migration in Central and Eastern Europe: the Case of Ukraine. United Nations. Geneva.

KUSHNIR, Iryna; TSARENKO, Olha; TSARENKO, Serhii. 2021. "Legal and organizational problems on identification of persons in activities of the State Border Guard Service of Ukraine” In: Juridical Tribune. Vol. 11, No. 1, pp.113-130.

LIBANOVA, Ekaterina. 2010. "External labor migration of the population of Ukraine" In: Economy of Ukraine. Vol. 2, p. 38-42.

MALINOVSKAYA, Olha. 2010. "Migration policy of Ukraine: state and prospects of development”. NISD. Kyiv, Ukraine.

MIKOLAICHUK, Maksym. 2010. Financial and economic mechanism for ensuring sustainable balanced development of the region. NASM. Kyiv, Ukraine.

MOLINARI, Caterina. 2019. "The EU and its Perilous Journey through the Migration Crisis: Informalization of the EU Return Policy and Rule of Law Concerns" In: European Law Review. Vol. 44, No. 6, pp. 824-840.

POTEMKINA, Olga. 2015. "European Migration Agenda" - a new turn in the EU Migration Policy” In: Contemporary Europe. Vol. 4, pp. 28-40.

PRESIDENT OF UKRAINE. 2011. On the Concept of State Migration Policy. Decree of the President of Ukraine № 622/2011 from 2011. Available online. In: http://zakon3.rada.gov.ua/laws/show/622/2011. Date of consultation: 05/12/2020.

PRESIDENT OF UKRAINE. 2014. On the optimization of the system of central executive bodies. Decree of the President of Ukraine № 442 from 2014. Available online. In: http://zakon5.rada.gov.ua/laws/show/442-2014\%Do\% BF. Date of consultation: 05/12/2020. 
PROVINE, Doris Maria. "Making People Illegal: What Globalization Means for Migration and Law" In: Journal of Law and Society. Vol. 36, No. 2, pp. 292-296.

SADYKOVA, Larysa. 2016. "The New Line of the European Union in Migration Domain: Emphases and Mechanisms" In: Ezhegodnik IIS. MGIMOUniversity. Vol. 1, No. 15, pp. 13-19.

UNITED NATIONS. 1951.Convention and protocol relating to the Status of Refugees. Available online. In: https://cms.emergency.unhcr.org/ documents/11982/55726/Convention+relating+to+the+Status+of + Refugees+\%28signed +28+July+1951\%2C+entered+into+force+22+ April $+1954 \% 29+189+$ UNTS $+150+$ and +Protocol+relating+to+the+ Status+of+Refugees $+\% 28$ signed $+31+$ January $+1967 \% 2 \mathrm{C}+$ entered + into+force+4+ October+1967\%29+6o6+UNTS+267/obf3248a-cfa84a60-864d-65cdfece1d47. Date of consultation: 05/12/2020.

USSR. 1990. Declaration on the state sovereignty of Ukraine. Law № 55XII from 1990. Available online. In: https://zakon.rada.gov.ua/laws/ show/55-12\#Text. Date of consultation: 05/12/2020.

VERKHOVNA RADA OF UKRAINE. 1984. Code of Administrative Offenses of Ukraine. Law № 8073-X. Available online. In: https://zakon.rada.gov. ua/laws/show/80731-10\#Text. Date of consultation: 05/12/2020.

VERKHOVNA RADA OF UKRAINE. 1991. On Rehabilitation of Victims of Political Repression in Ukraine. Law № 962-XII from 1991. Available online. In: https://zakon.rada.gov.ua/laws/show/962-12\#Text. Date of consultation: 05/12/2020.

VERKHOVNA RADA OF UKRAINE. 1992. On approval of the Provisional Regulation on the Procedure for Determining the Status of Refugees from the Republic of Moldova and Providing Assistance to Them. Resolution of the Cabinet of Ministers of Ukraine № 378 from 1992. Available online. In: https://zakon.rada.gov.ua/laws/show/378-92\%Do\%BF\#Text. Date of consultation: 05/12/2020.

VERKHOVNA RADA OF UKRAINE. 1994. On the Procedure for Leaving Ukraine and Entering Ukraine by Citizens of Ukraine. Law № 3857XII from 1994. Available online. In: https://zakon.rada.gov.ua/laws/ show/3857-12\#Text. Date of consultation: 05/12/2020.

VERKHOVNA RADA OF UKRAINE. 1996. On approval of the Program to combat illegal migration for 1996-1997. Resolution of the Cabinet of Ministers of Ukraine № 83 from 1996. Available online. In: https:// zakon.rada.gov.ua/laws/show/83-96-\%Do\%BF\#Text. Date of consultation: 05/12/2020. 
Yurii Kuryliuk, Mariia Slyvka y Yaroslav Kushnir

490

Legal regulation of combating illegal migration in Ukraine and the EU

VERKHOVNA RADA OF UKRAINE. 1996. Constitution of Ukraine. Available online. In: http://zakon4.rada.gov.ua/laws/show1254k/96-вp. Date of consultation: 05/12/2020.

VERKHOVNA RADA OF UKRAINE. 1999. On the Principles of the State Policy of Ukraine in the Field of Human Rights. Resolution of the Verkhovna Rada of Ukraine № 757-XIV from 1999. Available online. In: https:// zakon.rada.gov.ua/laws/show/757-14\#Text. Date of consultation: 05/12/2020.

VERKHOVNA RADA OF UKRAINE. 2001. Criminal Code of Ukraine. Law № 2341-III. Available online. In: https://zakon.rada.gov.ua/laws/ show/2341-14\#Text. Date of consultation: 05/12/2020.

VERKHOVNA RADA OF UKRAINE. 2001. On Amendments to Certain Legislative Acts of Ukraine on Combating Illegal Migration. Law № 2247III. Available online. In: https://zakon.rada.gov.ua/laws/show/224714\#Text. Date of consultation: 05/12/2020.

VERKHOVNA RADA OF UKRAINE. 2001. On Citizenship of Ukraine. Law № 2235-III. Available online. In: https://zakon.rada.gov.ua/laws/ show/2235-14\#Text. Date of consultation: 05/12/2020.

VERKHOVNA RADA OF UKRAINE. 2001. On Immigration. Law № 2491III from 2001. Available online. In: https://zakon.rada.gov.ua/laws/ show/2491-14\#Text. Date of consultation: 05/12/2020.

VERKHOVNA RADA OF UKRAINE. 2003. On Freedom of Movement and Free Choice of Residence in Ukraine. Law № 1382-IV. Available online. In: https://zakon.rada.gov.ua/laws/show/1382-15\#Text. Date of consultation: 05/12/2020.

VERKHOVNA RADA of Ukraine. 2004. On Ukrainians Abroad. Law № 1582IV from 2004. Available online. In: https://zakon.rada.gov.ua/laws/ show/1582-15\#Text. Date of consultation: 05/12/2020.

VERKHOVNA RADA OF UKRAINE. 2011. On Refugees and Persons in Need of Additional or Temporary Protection. Law № 3671-VI from 2011. Available online. In: https://zakon.rada.gov.ua/laws/show/367117\#Text. Date of consultation: 05/12/2020.

VERKHOVNA RADA OF UKRAINE. 2011. On the legal status of foreigners and stateless persons. Law № 3773-VI from 2011. September 9, 2011. Available online at: https://zakon.rada.gov.ua/laws/show/377317\#Text. Date of consultation: 05/12/2020. 
VERKHOVNA RADA OF UKRAINE. 2012. Criminal Procedure Code of Ukraine. Law № 4651-VI. Available online. In: https://zakon.rada.gov. ua/laws/show/4651-17\#Text. Date of consultation: 05/12/2020.

VERKHOVNA RADA OF UKRAINE. 2012. On Employment. Law № 5067VI from 2012. Available online. In: https://zakon.rada.gov.ua/laws/ show/5067-17\#Text. Date of consultation: 05/12/2020. 
Vol. 39 N $^{\circ} 71$

Esta revista fue editada en formato digital y publicada en diciembre de 2021, por el Fondo Editorial Serbiluz, Universidad del Zulia. Maracaibo-Venezuela 